\title{
Companies Financial Performance as a Signal for Investor in Predicting Stock Price, with Macroeconomics Variable as Control Variable
}

\author{
Pristina Hermastuti Setianingrum*, Doddi Prastuti \\ Department of Management \\ Sekolah Tinggi lmu Ekonomi Indonesia \\ Jakarta, Indonesia \\ *pristina@stei.ac.id, dodi_prastuti@stei.ac.id
}

\begin{abstract}
The purpose of this research is to measure and to analyze the impact of financial ratios to companies' stock price, while using macroeconomics variable as control variable. The financial ratios used in this research are: price earnings ratio, price to book value, net profit margin and return on equity. The samples of this research are stock price of 25 companies in consumption and financial sectors in Indonesia stock market during period 2009 to 2016, therefore there are 200 panel balance observation. Using Fixed Effect Model, result of the research shows that companies' financial ratios have strong influence on stock price. Test of hypotheses showed that together all financial ratios have significant impact on stock price. However, partially, only price earnings ratio and price to book value have significant impact on stock price.
\end{abstract}

Keywords: stock price, price earnings ratio, price to book value, net profit margin, return on equity, Indonesia stock market

\section{INTRODUCTION}

One of the reasons that an investor invests in shares of the stock markets is because of hoping to achieve the positive incomes for his/her investments. Stock returns are measured from changes in the market price of the next period and the dividends received. The results of the stock successes in theory are heavily influenced by many good factors that are in the company's financial control and also factors that are happening in the outside control of the company's hand. In this research, some factors that are in company's control that is used is the company's financial ratio. On the other hand, the factor those are outside company's control that is used is gross domestic product, inflation rate and interest rate.

Financial ratios are still one of the variables that are generally used to measure the success of a business in managing businesses. Financial ratios can be grouped into a number of groups, namely: liquidity, financial leverage ratio, asset management, profitability and market value [1]. In this research financial ratio that is used are ratio profitability and market ratio.

There are several ratios which are grouped in the profitability ratio. In this research, there are only two ratios that are used. Those ratios are net profit margin and return on equity. The net profit margin is chosen because it uses to measure the net profit after all the operational cost and company's load cost has been paid. A portion of the net profit can be allocated to be distributes as dividends, so this ratio is more relevant in influencing fluctuations in share prices from an internal perspective. The return on equity ratio is chosen because this ratio has taken place to reflect on the efficiency of the company in managing its equity, so that the theory is very relevant to the relationship with an understanding.

This research uses the market ratio because this ration can give signals to the investors to take action on selling or buying stock on a company. The market ratios that are used in this research are price to book value ratio and price earnings ratio.

One research stated that investors obtain profits economically valuable from stock investments that they have done with observing those financial ratios. From the research that they have done, financial ratio is still an important factor in influencing stock price [2].

Macroeconomic condition in a country theoretically can influence business cycles of a country. In order for the business in the company can grow therefore it needs to increase sales. Sales can increase if only the consumers increase their purchases of the company's products that are involved. The consumers will increase their consumption if their income also increases. The income in the macro economy is measured by gross domestic product. In addition to income, the spending patterns are also influenced by the level of inflation and the level of interest that occurs.

Macro economy condition and financial market which are the main factors of outside the control of companies, can affect the market participants preferences so that in turn they affect how they are interpreting changes in aggregate earnings [3].

Based on the background mentioned above, the topic of this research is Companies Financial Performance Signal for Investor in Predicting Stock Price, with Macroeconomics Variable as Control Variable Study Case on Consumption Sector and Financial Sector in Indonesia Stock Exchange.

In this research, financial ratios are used as a proxy to measure the financial performance of companies. The purpose of this research is to find out how big the financial ratios of the 
company towards stock prices with the macro economic variables as the control variables.

\section{BACKGROUND THEORY}

\section{A. Theoretical Framework}

The company's financial statements are one source of information about the financial condition of a company. Parties outside the company are using a company's financial statements to find out how the company's financial condition is. The parties outside the company include: government agencies, financial institutions, shareholders, investors, consultants, researchers and others. From the internal side of the company, financial statements are one of the tools used to measure the performance achievements for the management team responsible for managing the company

The performance of the company's management team can be judged by increasing standard financial measurement tools from one period to the next. Financial ratios are one measurement commonly used to compare the company's financial performance. To see the development of a company's financial performance from one period to another, time series financial ratio data is used. Whereas to compare the financial performance among several companies, the financial ratios cross section data is used.

Profitability is a measuring tool used by financial analysts to evaluate the profit of a company at a certain sales level [4]. Profitability ratio is a ratio used to measure how the efficiency of a company in using its assets and managing its business operations [1], whereas according to Gitman and Zutter, profitability ratio is a ratio that measures whether a company's profit is sufficient, relative to the assets invested by the company [5]. The three definitions above agree that profitability ratios are used to measure the efficiency of a company in managing its operations. Net profit margin (NPM) is a ratio that measures how much net income a company receives for every Rupiah of company sales. This ratio basically measures how efficient a company is in managing its business operations. Return on equity (ROE) is a ratio that measures how much net income is received by a common shareholder in every Rupiah equity invested.

The market value ratio as it is so called, because this ratio uses the stock market price as one of the variables in the formula. The price earnings (PER) measures how much rupiah an investor must pay for a company's stock for every one rupiah earning at this time. Stock analysts are cautious in analyzing in PER, they argue that stocks that have a low PER provide an opportunity for a better bargaining position when compared to stocks that have a high PER. However, it should be remembered that the company's current earnings can be different from the company's earnings in the future. In investing, investors are oriented towards the future. So that a stock that has a high PER, still has a potential bargaining position if in the future the growth of the company's earnings and dividends are expected to give a fast growth rate. The results of empirical research conducted do not give the same results about the pattern of the relationship between PER and expectation yields. So the theoretical concept which states that investing in shares that have a low PER will provide a greater return on expectations when compared to investing in stocks that have high PER not always empirically proven [6]. Market to book ratio is a ratio that measures the market price ratio of a stock to the book value of the shares. Market to book ratio measures how the company manages its business to create value. Company shares that are expected to produce a relatively high return compared to the risk, are usually sold at a higher M/B multiple.

Net profit margin is the percentage of net profit obtained by a company. From these profits the company can allocate funds to be distributed as dividends. Theoretically, it is expected that increased profits can provide dividends that also increase. Thus the company's shares are increasingly attractive for investors to buy these shares. The more net profit margin increases therefore it is expected to increase stock prices.

$\mathrm{ROE}$ is a ratio that shows the returns for shareholders. Every investor will prefer investment returns that are increasingly high, with the appropriate level of risk. Increased return on equity is expected to increase share prices.

A stock that has a low price earnings ratio is expected to still have a chance to increase greater when compared to stocks with a price earnings ratio that is already high. However, because there is no specific number agreed upon as a criterion for a high or low price earnings ratio, it is estimated that the impact of the price earnings ratio on stock prices will fluctuate.

The hypothesis proposed in this study is: it is predicted that there is a significant influence of financial ratio variables on the company's stock price in the industry, with macroeconomic variables as control variables.

In the industry, with given macroeconomics conditions, the fundamental strength of a company which is shown by the company's ability to generate profits as indicated by the ratio of NPM and ROE as well as the factor of market perception of the company reflected by PER and PBV, in theory they will move in the direction of the average company price in the industry.

Investors will be interested in investing in stocks with better financial ratios compared to other companies. The higher the value of NPM, ROE means the more capable the company is in generating profits after tax. The increase in profits means also increasing the welfare of shareholders because the company will be able in a better way to pay dividends.

The higher PER value of a company shows that the market appreciates the company's shares many times compared to the earnings per share of the company. Likewise, if the PBV of a company is higher than other companies, then this shows a high market appreciation of the company's shares compared to the book value. In other words, the higher PER and PBV value also reflects the increasing value of the company.

\section{B. Literature Review}

The research by Bannigidadmath and Narayan observed that in India the prediction results in sectors returns can be used to predict market returns [2]. Financial ratios are an important factor in analyzing stock returns. 
financial industry, there are 17 companies that meet the requirements. Thus there are 200 observations.

The independent variables used in this study are net profit margin (NPM), return on equity (ROE), Price earnings ratio (PER) and market to book ratio (PBV). Macroeconomic variables in this study are used as control variables, namely inflation and interest rates. The stock price is used as an independent variable.

\section{B. Regression Model}

The multiple regression model used in this research is as follow: operational profitability that is in line with current costs and revenues, is a better predictor of returns, which results depend on whether the denominator is Total Assets or Market Value Equity. From the results of the Foerster et al. [7] research by adding cash flow variables, it is obtained that the measurement of return on assets and yields using the direct calculated cash flow method (DMCF) generally produces better predictions for stock returns compared to the method Cash flows, which are calculated indirectly, are generally superior compared to using data from the income statement.

Research by Charles et al. [8] investigate the stock returns on the international market whether it is more predictable from the fundamentals of the company including the main financial ratios (dividend-price ratio, dividend-yield, earnings-price ratio, dividend-payout) ratio), technical indicators (price pressure, change in volume), and from short-term interest rates. Using monthly data on 16 stock markets in the Asia Pacific (including the U.S.) and 21 on European stock markets from 2000 to 2014, it was found that financial ratios showed weak predictive ability with small effect sizes with poor forecasting performance. In contrast, price pressures and interest rates have proven to be strong predictors for stock returns with large effect sizes and satisfactory out-of-sample forecasting performance.

Research by Arkan [9] tests the ability of 12 types of financial ratios in predicting stock prices from 2005 - 2014 in three sectors in Kuwait's financial markets. The results show that some ratios produce a positive and significant relationship to market price behavior and trends. In the ROA industry sector, ROE and net profit ratios are the most effective ratios for predicting stock prices while in the service sector and the most effective investment ratios for predicting stock prices are ROA, ROE, P / E and EPS. This study concludes that to predict stock prices can rely on a set of financial ratios.

\section{METHOD}

\section{A. Population and Sample}

The population in this study is the financial statements of all companies in the consumption and financial sectors listed on the Indonesia Stock Exchange 2009-2016. The method used to determine the sample is the purposive sampling method. The criteria used to select the sample in this study are: choosing the sector with the largest capitalization, namely the consumption sector and the financial sector, and then selecting companies by random sampling, i.e. companies that publish annual financial reports during observations in 2009 to 2016. In the selected consumption sector 8 companies that meet the criteria. In the

$$
\begin{aligned}
\mathrm{Y}= & \mathrm{a}+\mathrm{b} 1 \mathrm{LOGINF}+\mathrm{b} 2 \mathrm{LOGBNGA}+\mathrm{b} 3 \mathrm{LOGPER}+ \\
& \mathrm{b} 4 \mathrm{LOGPBV}+\mathrm{b} 5 \mathrm{NPM}+\mathrm{b} 6 \mathrm{ROE}+\mathrm{e}
\end{aligned}
$$

Where:

$\begin{array}{ll}\text { Y } & : \text { the stock price } \\ \operatorname{logINF} & : \text { inflation } \\ \text { logBNGA } & : \text { interest } \\ \text { logPER } & : \text { is the price earnings ratio } \\ \text { PBV log } & : \text { a price to book value ratio } \\ \text { NPM } & : \text { a net profit margin } \\ \text { ROE } & : \text { return on equity }\end{array}$

Log models for inflation, interest, PER and PBV variables are used for data smoothing

\section{The Statistical Hypotheses}

The statistical hypothesis in this study is as follows: it is predicted that there is a significant effect of the variable financial ratio impact on the share price, holding macroeconomic variables as control variables.

$$
\text { Ho: } \beta 1=\beta 2=\beta 3=\beta 4=\beta 5=\beta 6=0 .
$$

There is no significant influence of company's financial ratio on stock price

$$
\text { Ha: } \beta 1 \neq \beta 2 \neq \beta 3 \neq \beta 4 \neq \beta 5 \neq \beta 6 \neq 0 \text {. }
$$

There is significant influence of company's financial ratio on stock price

\section{RESULTS AND DISCUSSION}

\section{A. Research Result}

The consumption sector in Indonesian stock market consists of five sub sectors, namely: food and beverages, cigarettes, pharmaceutical, cosmetic and household goods and appliances. Whereas the financial sector consists of five sub sectors, they are: banks, financing companies, securities companies and others.

From the sampling process using stratified random sampling there are eight companies in consumption sector and seventeen companies in financial sector chosen. They are: 6 food and beverage companies, 2 pharmaceutical companies, 11 banks, 3 financing companies, and 3 insurance companies

Price earnings ratios for companies in consumption sector are fluctuate; it increases from 2009 to 2014 and then decreases afterwards. The price to book value ratios across industry is very dispersing, with the lowest 0.63 and the highest 58.48. 
company. The reason that this relation does not hold in this research, among others, are: this research used 25 companies as sample and the companies chosen as sample in this study are involve in very different business sectors.

From the results of the t-statistic test, the significant effect is PER, probability $0.0105<5 \%$; and PBV, probability 0.0000 $<5 \%$. While NPM and ROE do not have a significant effect on stock prices.

TABLE II. CROSS-SECTION FIXED (DUMMY VARIABLES) value ratio range between 0.3 to 4.96 ; NPM fluctuate with the highest is $44.99 \%$ and the lowest $0.43 \%$. In the financial sector, generally banks have higher ROE compare to the insurance and financing companies.

\section{B. Test of Classical Assumptions}

The data in this study were processed using the Eviews program. The steps taken are as follows: Estimating CEM; estimating FEM; do the Chow test, if the FEM is selected then do the REM estimation; the Hausman test, if the selected REM is not an LM test.

After performing these steps, therefore from the Chow test results obtained a probability of $0.0000<5 \%$ so that the model chosen is FEM. The next step is to do REM and Hausman test. From the Hausman test results with a probability of 0.0022 $<5 \%$, the FEM model was chosen.

The classic assumption test was also carried out in this study with the following results. From the results of the probability, the normality test was $0.590080>5 \%$. This means that the data meet the normality test criteria. From the results of the multicollinearity test, all the numbers in the research variable matrix are $<0.8$. This means there is no multicollinearity between research variables. From the heteroscedacity test results all the probabilities of the research variables $>5 \%$, so there is no heteroscedacity in this study. From the autocorrelation test results obtained that there is no positive autocorrelation.

\section{Analysis of Regression Result}

TABLE I. FIXED EFFECT MODEL

\begin{tabular}{|l|c|c|c|c|}
\hline Variable & Coefficient & Std. Error & t-Statistic & Prob. \\
\hline C & 7.953120 & 0.478960 & 16.60496 & 0.0000 \\
\hline LOGINF & 0.303594 & 0.058718 & 5.170388 & 0.0000 \\
\hline LOGBNGA & -0.775650 & 0.217348 & 3.568703 & 0.0005 \\
\hline LOGPER & 0.210594 & 0.081358 & 2.588469 & 0.0105 \\
\hline LOGPBV & 0.519338 & 0.090157 & 5.760382 & 0.0000 \\
\hline NPM & -0.003483 & 0.003145 & 1.107548 & 0.2696 \\
\hline ROE & 0.003735 & 0.003517 & 1.061903 & 0.2898 \\
\hline
\end{tabular}

From the table 1 we get the following regression results:

$$
\begin{aligned}
\text { SPit }= & 7.953120+0.303594 \text { LOGINFit }-0.775650 \\
& \text { LOGBGNAit }+0.210594 \text { PERit }+0.519338 \\
& \text { LOGPBVit }-0.003483 \text { NPMit }+0.003735 \text { ROEit }+\mathrm{e}
\end{aligned}
$$

The regression result showed that across industry PER and ROE have positive relation with stock price, while PBV and NPM have negative relation with stock price. Basic finance theory said that usually net profit margin should have positive relation with stock price. This relation is true if applied to one

\begin{tabular}{|l|l|l|l|}
\hline R-squared & 0.959945 & Mean dependent var & 7.159501 \\
\hline Adjusted R-squared & 0.952834 & S.D. dependent var & 1.719546 \\
\hline S.E. of regression & 0.373446 & Akaike info criterion & 1.009493 \\
\hline Sum squared resid & 23.56902 & Schwarz criterion & 1.520732 \\
\hline Log likelihood & -69.94929 & Hannan-Quinn criter. & 1.216384 \\
\hline F-statistic & 135.0052 & Durbin-Watson stat & 0.867979 \\
\hline Prob(F-statistic) & 0.000000 & \multicolumn{2}{|c}{ Sources: data processed } \\
\hline
\end{tabular}

Adjusted R-squared $=0.952834$, meaning that $95.28 \%$ of the stock price can be explained by independent variables namely PER, PBV, NPM and ROE with inflation and interest rates as control variables. The remaining $4.72 \%$ is explained by other factors not examined.

Probability test (F-statistic): $0.0000<5 \%$, which means that the variables PER, PBV, NPM and ROE have a significant effect on stock prices, with inflation and interest rates as control variables.

\section{CONCLUSION}

Result of this research showed that company's performance measured by PER and PBV have significant effect to stock price for companies in consumption and financial sectors. Whereas NPM and ROE do not have significant effect to stock price. Adjusted R-square has high value, which means stock price fluctuation can be explained by PER, PBV, NPM and ROE holding macroeconomics as control variable.

\section{REFERENCES}

[1] S. A. Ross, R. W. Westerfield, and B. D. Jordan, Fundamentals Of Corporate Finance, New York : Mc Graw Hill Education 11th edition, 2016.

[2] D. Bannigidadmath and P. K Narayan, "Stock return predictability and determinants of predictability and profits", Emerging Market Review, Vol. 26, pp 153-173, March 2016.

[3] L. Zolotoy, J. R. Frederickson and J. D Lyon,"Aggregate earnings and stock market return: The good, the bad and the state-dependent", Journal of Banking and Finance, volume 77, pp 157-172, April 2017.

[4] A. J. Keown, J. D Martin, and J. W. Petty, Foundations of Finance,New York: Pearson International, 9th edition, 2017.

[5] Y L. J. Gitman, and C. J. Zutter, Principles Of Managerials Finance, New York: Pearson Education Limited 14th edition, 2015M. Young, The Technical Writer's Handbook. Mill Valley, CA: University Science, 1989.

[6] Z. Bodie, A. Kane, and A. J. Markus. Essentials of Investments, New York : Mc. Graw Hill International edition, 5th edition, 2003

[7] S. Foerster, J. Tsagarelis and G. Wang,"Are Cash Flows Better Stock Return Predictors Than Profits ?", Financial Analysts Journal, CFA Institute, Vol 73, pp 74-98, 2017. 
[8] A. Charles, O. Dame and J.H. Kim,"International Stock Return Predictability: Evidence from new statistical test", International Review of Financial Analysis, June, 2016.
[9] T. Arkan,"The Importance of Financial Ratios in Predicting Stock Price Trends: A Case Study in Emerging Markets", Finanse, Rynki Finansowe, Ubezpieczenia nr, 1(79), 2016. 